\title{
PRODUCING ISLAM(S) IN CANADA
}

\section{On Knowledge, Positionality, and Politics}

Edited by Amélie Barras, Jennifer A. Selby, and Melanie Adrian

During the last twenty years, public interest in Islam and how Muslims express their religious identity in Western societies has grown exponentially. In parallel, the study of Islam in the Canadian academy has grown in a number of fields since the 1970s, reflecting a diverse range of scholarship, positionalities, and politics. Yet, academic research on Muslims in Canada has not been systematically assessed.

In Producing Islam(s) in Canada, scholars from a wide range of disciplines come together to explore what is at stake regarding portrayals of Islam(s) and Muslims in academic scholarship. Given the centrality of representations of Canadian Muslims in current public policy and public imaginaries, which effects how all Canadians experience religious diversity, this analysis of knowledge production comes at a crucial time.

AMÉLIE bARRAS is an associate professor in the Department of Social Science at York University.

JENNIFER A. SELBY is an associate professor in the Department of Religious Studies and an affiliate member of the Department of Gender Studies at Memorial University.

MELANIE ADRIAN is an associate professor in the Department of Law and Legal Studies at Carleton University. 
This page intentionally left blank 


\section{Producing Islam(s) in Canada}

On Knowledge, Positionality, and Politics

EDITED BY AMÉLIE BARRAS, JENNIFER A. SELBY, AND MELANIE ADRIAN 
(C) University of Toronto Press 2021

Toronto Buffalo London

utorontopress.com

Printed in the U.S.A.

ISBN 978-1-4875-0500-4 (cloth)

ISBN 978-1-4875-3133-1 (EPUB)

ISBN 978-1-4875-2788-4 (paper)

ISBN 978-1-4875-3132-4 (PDF)

\section{Library and Archives Canada Cataloguing in Publication}

Title: Producing Islam(s) in Canada : on knowledge, positionality, and politics / edited

by Amélie Barras, Jennifer A. Selby, and Melanie Adrian.

Names: Barras, Amélie, editor. | Selby, Jennifer A., editor. | Adrian, Melanie, editor.

Description: Includes bibliographical references and index.

Identifiers: Canadiana (print) 20210339136 | Canadiana (ebook) 20210339144 | ISBN

9781487505004 (cloth) | ISBN 9781487527884 (paper) | ISBN 9781487531331

(EPUB) | ISBN 9781487531324 (PDF)

Subjects: LCSH: Islam - Research - Canada. | LCSH: Islam - Study and teaching -

Canada. | LCSH: Islam - Canada. | LCSH: Muslims - Canada. | LCSH:

Canada - Religion.

Classification: LCC BP43.C3 P76 2021 | DDC 297.0971 - dc23

This book has been published with the help of a grant from the Federation for the Humanities and Social Sciences, through the Awards to Scholarly Publications Program, using funds provided by the Social Sciences and Humanities Research Council of Canada.

University of Toronto Press acknowledges the financial assistance to its publishing program of the Canada Council for the Arts and the Ontario Arts Council, an agency of the Government of Ontario.

Canada Council for the Arts

Conseil des Arts du Canada

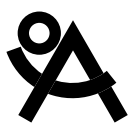

ONTARIO ARTS COUNCIL CONSEIL DES ARTS DE L'ONTARIO

an Ontario government agency un organisme du gouvernement de I'Ontario

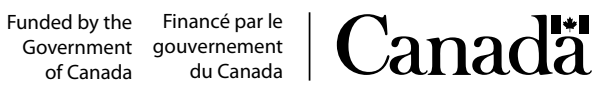

